\title{
Components of Partial Resistance in the Slash Pine-Fusiform Rust Pathosystem
}

\author{
R. A. Schmidt, K. P. Gramacho, T. Miller, and C. H. Young
}

First and third authors: School of Forest Resources and Conservation, Institute of Food and Agricultural Sciences, University of Florida, Gainesville, PO Box 110410, 32611-0410. Second author: CEPLAC/CEPEC/SEFIT, Cx. PO 07, 45600-000, Itabuna, BA Brazil. Fourth author: U.S. Department of Agriculture, Forest Service, Resistance Screening Center, 1579 Brevard Road, Asheville, NC $28806-9561$. Publication R-07354 Florida Agricultural Experiment Station.

Accepted for publication 1 June 2000.

\begin{abstract}
Schmidt, R. A., Gramacho, K. P., Miller, T., and Young, C. H. 2000. Components of partial resistance in the slash pine-fusiform rust pathosystem. Phytopathology 90:1005-1010.

Progeny of rust-resistant, open-pollinated slash pine families exhibited components of partial resistance in greenhouse tests. Nine-month-old seedlings of some resistant families had (i) a greater frequency of short galls ( $\leq 25 \mathrm{~mm}$ long), and (ii) fewer sporulating galls compared with other resistant and susceptible families when exposed to Cronartium quercuum f. sp. fusiforme in greenhouse tests. These components of partial resistance were evident with (i) mixed- or single-gall inocula, (ii) varying inoculum concentration, and (iii) inoculation of wounds or intact tissues. Inocula effects were nonsignificant, but family effects were highly significant $(P=$
\end{abstract}

ABSTRACT
$0.001-0.0001)$ for total galls (TG) and short galls (SG). Multivariate family means (TG-SG clusters) were highly significant $(P=0.0001)$. Short galls decreased on all families with an increase in inoculum concentration. In 36 field trials (12 locations $\times 3$ years) a family which exhibited components of partial resistance in greenhouse tests exhibited lower disease incidence ( $\%$ trees infected), lower disease severity (galls per tree), and less variability in disease incidence and severity among trials compared with other resistant families. Partially resistant families would be useful for tree improvement and for research into the genetics and mechanisms of resistance in the slash pine-fusiform rust pathosystem.

Additional keywords: Cronartium quercuum f. sp. fusiforme, incomplete resistance, pine stem rust, Pinus elliottii var. elliottii.
Parlevliet (26) defined partial resistance as a form of incomplete resistance where spore production is reduced in spite of a susceptible infection type. He included infection frequency, latent period, lesion size, spore production and infectious period as rate-reducing components of partial resistance. Partial resistance has been described most with foliar diseases of annual plants caused by obligate parasites $(27,38)$ and with leaf rusts of perennial plants, e.g., coffee leaf rust (6) and poplar leaf rust (30). Hoff and McDonald (11) suggested that the reduced frequency of secondary needle lesions and slow fungal growth in secondary needles and stems of western white pine (Pinus monticola Dougl.) were evidence of horizontal resistance to Cronartium ribicola J. C. Fisch. controlled by several or many genes. McDonald and Dekker-Robertson (22) indicated that selected populations of $P$. monticola fit most of the seven characteristics of horizontal resistance reviewed by Simmonds (39).

Resistance of slash pine (Pinus elliottii [Engelm.] var. elliottii) to Cronartium quercuum (Berk.) Miyabe ex Shirai f. sp. fusiforme was initially assessed by the presence or absence of galls (percentage of trees with one or more galls) in field trials $(2,35)$ and in greenhouse tests $(7,12)$. Subsequently, reaction types were recognized in greenhouse tests $(23,50,52)$ from which a performance index was developed. This index provides improved correlation of relative resistance among families between greenhouse inoculations and field trials (52). The index includes the percentage of (i) "SYMNOS", seedlings with purple stem lesions but no subsequent gall formation, (ii) rough galls, with necrotic

Corresponding author: R. A. Schmidt; E-mail address: rasch@gnv.ifas.ufl.edu

Publication no. P-2000-0705-03R

(C) 2000 The American Phytopathological Society sunken areas, (iii) short galls $\leq 25 \mathrm{~mm}$ long, and (iv) apparently healthy seedlings. Families with greater frequencies of these resistant reaction types received a higher performance index. Snow (41) reported that round galls (lower length/width ratio) were associated with resistance of loblolly pines (Pinus taeda L.) in field trials. Recently Walkinshaw (49) reported that resistance in slash pine families was associated with decreased gall length.

Chappelka et al. (4) found that $18 \%$ of 347 galls in 8- to 14-year-old slash pine plantations did not produce aeciospores during a 4-year period, but family means were not recorded. The frequency of galls which did not sporulate in a 3-year field study was 24 to $56 \%$ (18). In greenhouse inoculations, Kuhlman and Matthews (21) reported that sporulation was affected by pine family and inoculum source. Schmidt and Miller (36) reported that pycnial sporulation was inversely related to inoculum concentration and that aecial sporulation was inversely related to pycnial production.

Lower frequencies of galls, greater frequencies of short galls, and a lower frequency of sporulating galls are associated with relative resistance of slash pine to $C$. quercuum f. sp. fusiforme. The object of this paper is to document the consistent occurrence of these reaction types in several resistant slash pine families exposed to varying: (i) inoculum sources, (ii) inoculum concentrations, and (iii) inoculation techniques in greenhouse tests, and the stable performance of these families in field tests. We suggest that these resistant reaction types (short galls and nonsporulating galls) demonstrate partial resistance in the slash pinefusiform rust pathosystem.

\section{MATERIALS AND METHODS}

Pine families. Pine seedlings were progeny from windpollinated ramets established in seed orchards from scions grafted 
onto unspecified rootstocks. These half-sib progenies are referred to as families. Families for our studies were selected based on the percentage of trees with one or more galls in numerous field trials $(8,34,45)$. In our greenhouse tests this criterion would be similar to the total galls as reported here. Families for our studies were not selected based on gall size, a variable not measured in field trials. The designations partially resistant (PR), resistant (R), and susceptible (S) are used here to characterize the families based on the results of our experiments. The family designations are consistent among experiments.

Greenhouse inoculations. Tests were conducted at the USDA Forest Service, Resistance Screening Center (RSC) in Asheville, NC. Standard procedures were used (17) except as noted. These procedures included: (i) spray inoculation of rapidly growing 6 -week-old seedlings with an aqueous suspension of basidiospores at a concentration of 20,000 spores/ml (Concentrated Basidiospore Spray [CBS] method), (ii) incubation for $24 \mathrm{~h}$ in a dark moist chamber at $21^{\circ} \mathrm{C}$ and $>97 \%$ relative humidity, (iii) maintenance in a greenhouse at 15 to $20^{\circ} \mathrm{C}$ and $30 \mathrm{ft}$ candles light at plant height from fluorescent lamps for $12 \mathrm{~h}$ per day, and (iv) recording reaction types at 9 months. Procedures were identical in the inoculation concentration study where $2 \times 10^{4}, 2 \times 10^{5}$ and $1 \times 10^{6}$ basidiospores per $\mathrm{ml}$ of $\mathrm{H}_{2} \mathrm{O}$ were sprayed on seedlings. Procedures for wound inoculations differed in that $1 \times 10^{3}$ and $5 \times$ $10^{3}$ basidiospores per $\mathrm{ml}$ were pipetted with a $5 \mu \mathrm{l}$ droplet to the severed stem terminal of each seedling $(24,25)$.

Pine reaction types were recorded as large galls ( $>25-\mathrm{mm}$ long), short galls ( $\leq 25-\mathrm{mm}$ long), "SYMNOS" (purple stem lesions which do not develop into galls), and healthy (no observable symptoms). For analyses, total galls (large plus short) were calculated as the percentage of the seedlings inoculated; short galls were calculated as the percentage of total galls. As such, these variables were independent of one another. Analysis of variance (general linear model) tested family and inocula effects. A multivariate analysis identified family differences among clusters of $\mathrm{x}-\mathrm{y}$ (\% total galls$\%$ short galls) variables (Statistical Analysis, Inc. Cary, NC).

Inocula were basidiospores collected from germinating telia on red oak (Quercus rubra L.) leaves previously inoculated with aeciospores collected from galls on pines in the field (17). Individual-gall inocula were produced from aeciospores collected from a single stem gall; mixed-gall inocula were produced from a mixture of aeciospores collected from 6 to 20 galls. Prior to oak inoculations, aeciospores were vacuum dried and stored at $5^{\circ} \mathrm{C}$ in sealed ampules.

Seedlings for sporulation studies were moved from Asheville, North Carolina to Gainesville, Florida subsequent to symptom evaluation, replanted into $25.4-\mathrm{cm}$ pots and placed in a greenhouse $\left(20\right.$ to $32^{\circ} \mathrm{C}, 30 \mathrm{ft}$ candles, fluorescent lights, $12 \mathrm{~h}$ per day). The number of galls producing pycnial (November through December) or aecial sori (February through April) were recorded biweekly.

Field trials. Thirty-six plantings (12 locations $\times 3$ years $)$ were established in the southeastern Coastal Plain in FL, GA, AL, MS during 1987, 1989 and 1991 (34). Each family was represented by 50 trees in each planting, arranged in five 10-tree-row blocks. Galls were recorded annually (age 1 through 5 years) and the cumulative number of galls per tree (rust severity) and percentage of trees with at least one gall (rust incidence) was calculated for each family, location, and year.

\section{RESULTS}

Host reaction types in greenhouse inoculations. Standard $R S C$ inoculations: 20,000 spores $C B S$. In greenhouse inoculations with eight mixed-gall inocula (4 locations $\times 2$ years), a resistant family (PR1) exhibited an intermediate frequency of total galls (TG) $(\bar{X}=89 \%)$ and the greatest frequency of seedlings with short galls (SG) $(\bar{x}=55 \%)$ compared to another resistant family (R1) and a susceptible family (S1) (Figure 1). The average frequency of SG in families R1 and S1 was $18 \%$ and $7 \%$, respectively. Inocula effects were not significant for TG or SG but family effects were significant for TG and SG $(P=0.0001)$. Multivariate family means were significantly different $(P=0.0001)$.

In inoculations with two mixed-gall inocula and two single-gall inocula (each collected in field progeny trials from the family to be inoculated) the resistant family (PR1) exhibited an intermediate frequency of TG $(\bar{x}=74 \%)$ and the greatest frequency of SG $(\bar{x}=$ $49 \%$ ) compared with resistant family (R1) and susceptible family (S1) (Figure 2). The average frequency of short galls in families $\mathrm{R} 1$ and $\mathrm{S} 1$ was 10 and 7\%, respectively. Inocula effects were not significant for TG or SG but family effects were significant $(P=$ $0.0001)$ for $\mathrm{TG}$ and SG. Multivariate family means were significantly different $(P=0.0001)$.

In inoculations with 16 individual single-gall inocula collected from four families at four locations, family R1 and S1 again responded with a low frequency of SG, while the resistant family (PR2) exhibited an intermediate frequency of TG $(\bar{x}=85 \%)$ and the greatest frequency of SG $(\bar{x}=22 \%)$ (Figure 3). Inocula effects were not significant for TG or SG but family effects were significant $(P=0.001)$ for TG and SG. Multivariate family means were significantly different $(P=0.0001)$

Inoculum concentration tests. With increasing inoculum concentration, (mixed-gall source) resistant families PR1 and PR3 exhibited increasing frequency of $\mathrm{TG}$, but a decreasing frequency of SG (Figure 4). In the susceptible family S2, the frequencies of short galls were zero at the two highest inoculum concentrations.

Wound inoculations. In five tests where basidiospores from mixed-gall inocula were applied to wounds on seedlings, the resistant family PR3 responded similarly to the resistant family in the basidiospore spray inoculations; TG averaged $49 \%$ and SG averaged $41 \%$. In families R2 and S2 the frequencies of SG were significantly less, averaging $4 \%$ and $0.6 \%$, respectively (Fig. 5). Inocula effects were not significant for $\mathrm{TG}$ or $\mathrm{SG}$ but family effects for TG and SG were significant $(P=0.0001)$. Multivariate family means were significantly different $(P=0.0001)$.

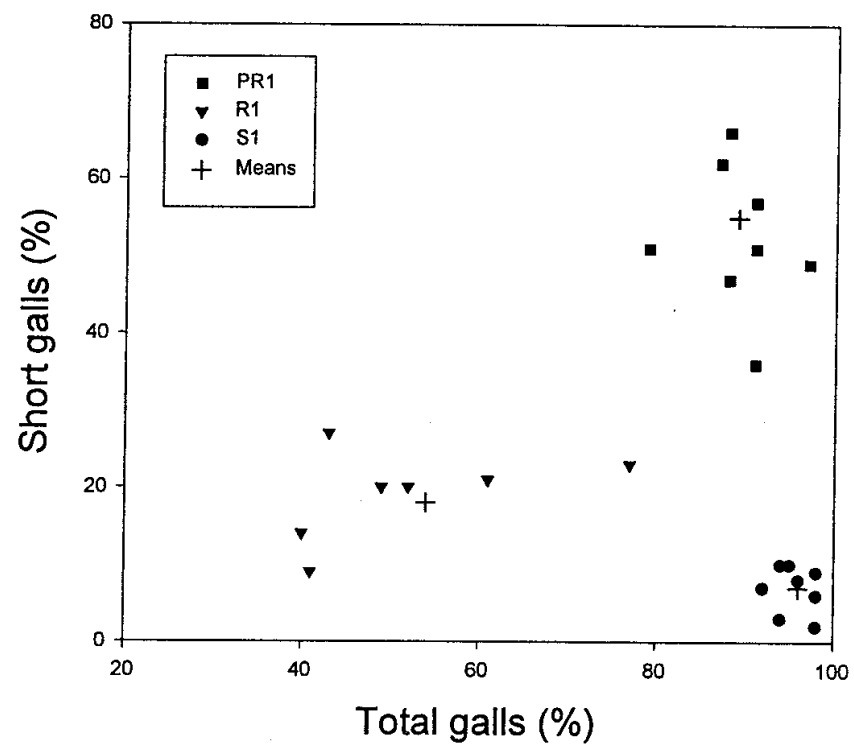

Fig. 1. Response of seedling progeny of resistant (PR1, R1) and susceptible (S1) open-pollinated slash pine families inoculated in the greenhouse with eight (4 locations $\times 2$ years) mixed-gall inocula of Cronartium quercuum $\mathrm{f}$. sp. fusiforme. Total galls are the percentage of seedlings with a gall, including large (> $25 \mathrm{~mm}$ long) and short ( $\leq 25 \mathrm{~mm}$ long) galls; short galls were calculated as the percentage of total galls. Each datum point is the average of four 20 -tree observations; $+=$ mean of multivariate cluster. There is one hidden observation in $\mathrm{R} 1$. 
Rust incidence and severity in field trials. In 36 field trials (12 locations $\times 3$ years) having a range of environmental conditions and rust potential, progenies of families PR1 and PR2 exhibited lower disease incidence and severity than families R1 and S1 (Table 1). Families PR1 and PR2 also exhibited less variability among trials than family $\mathrm{R} 1$; the standard error of estimate from regression analysis was $0.077,0.091$, and 0.132 for families PR2, PR3, and R1, respectively.

Sporulation in the greenhouse. Resistant family PR3 exhibited fewer large galls with pycnial or aecial sori $(25 \%)$ compared with resistant family R2 $(97.5 \%)$ and susceptible family S2 $(97.5 \%)$ (Table 2). In another population of 133 galls (primarily short galls) the frequency of sporulation (pycnial and/or aecial sori) on resistant family PR3 was 7.5\% (Table 2).

Sporulation frequency (pycnial and/or aecial sori) in the first year (seedlings age 10 to 15 months) was significantly greater on large galls $(92.3 \%)$ compared to short galls (40.5\%) (Table 3$)$. In the second year (age 25 to 27 months) sporulation frequency (aecial sori) was significantly greater on large galls $(49.2 \%)$ compared to short galls $(2.9 \%)$.

\section{DISCUSSION}

Our data show that some open-pollinated rust-resistant slash pine families exhibit components of partial resistance to $C$. quercuum f. sp. fusiforme, e.g., reduced numbers of lesions (fewer total galls), reduced lesion size (greater frequency of short galls) and reduced sporulation (reduced frequency of sporulation on large galls and infrequent sporulation on short galls). These components of partial resistance were expressed in response to mixed- and single-gall inocula from diverse sources (including multiple locations, years, and pine families) and in response to inoculation of wounded or unwounded tissues. All families (PR, R and $S$ ) exhibited increased total galls and decreased short galls with increase in inoculum concentration in greenhouse tests.

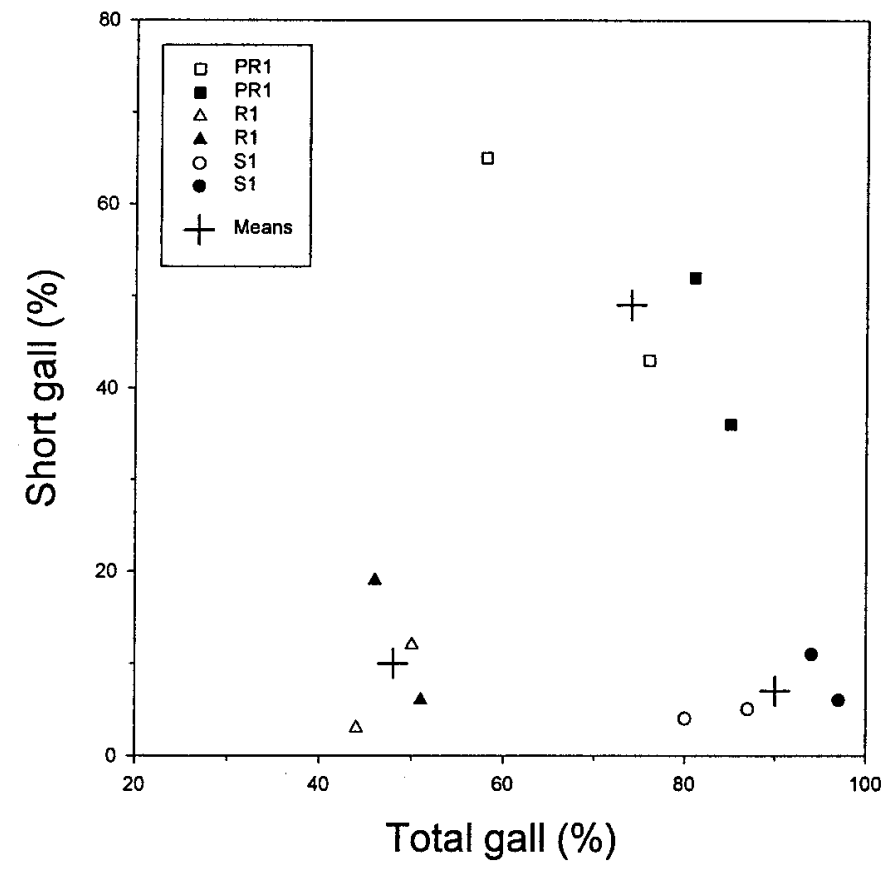

Fig. 2. Response of seedling progeny of resistant (PR1, R1) and susceptible (S1) open-pollinated slash pine families inoculated in the greenhouse with two single-gall (open symbols) and two mixed-gall (closed symbols) inocula of Cronartium quercuum f. sp. fusiforme. Total galls are the percentage of seedlings with a gall including large $(>25 \mathrm{~mm}$ long) and short $(\leq 25 \mathrm{~mm}$ long) galls; short galls were calculated as the percentage of total galls. Each datum point is the average of six 20 -tree observations; $+=$ mean of multivariate cluster.
Families exhibiting components of partial resistance in greenhouse tests exhibited lower disease incidence, lower disease severity, and greater stability among locations and years in field trials compared with other resistant families. Gall size and sporulation were not measured in field trials, but inoculum collection records suggest that a resistant family ( PR1) often had short galls with reduced and infrequent aecial sporulation (R. A. Schmidt, unpublished data).

There is theoretical and experimental evidence for qualitative and quantitative inheritance in the fusiform rust pathosystem. Cronartium quercuum f. sp. fusiforme is heteroecious (pine-oak) and macrocyclic. The repeating uredinial stage and the telia occur annually on oak leaves; aeciospores form on perennial pine galls and infect oak leaves, but do not reinfect pine. Fusiform rust is a

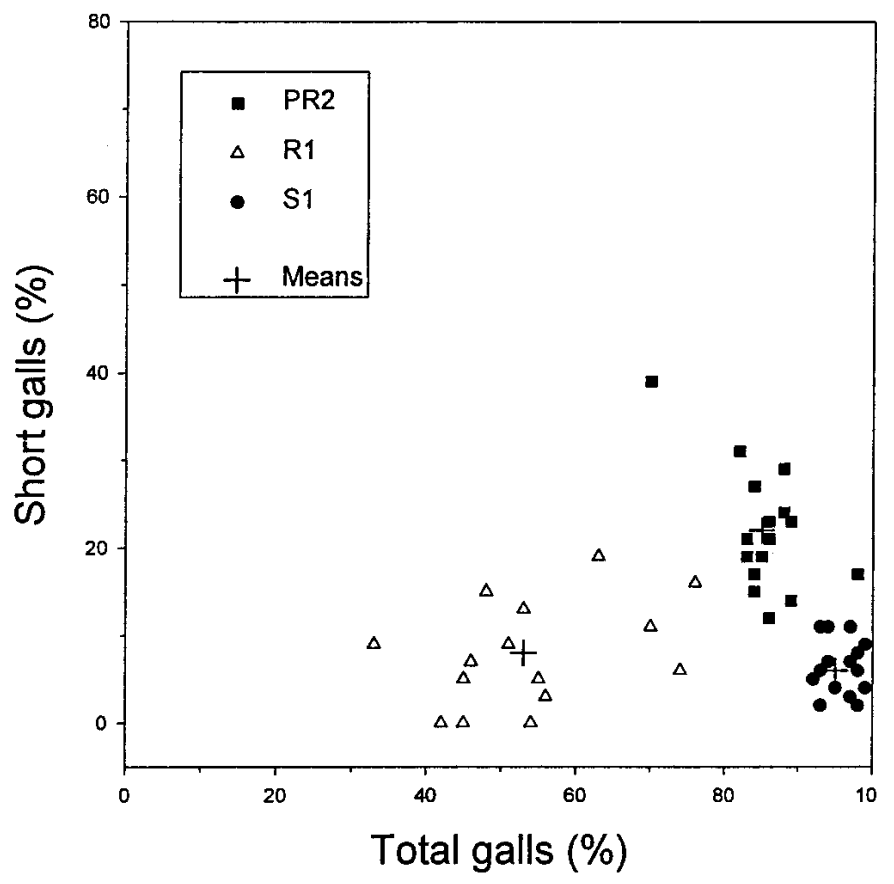

Fig. 3. Responses of seedling progeny of resistant (PR2, R1) and susceptible (S1) open-pollinated slash pine families inoculated in the greenhouse with 16 single-gall inocula (4 locations $\times 4$ families) of Cronartium quercuum $\mathrm{f}$. $\mathrm{sp}$. fusiforme. Total galls are the percentage of seedlings with a gall including large (> $25 \mathrm{~mm}$ long) and short $(\leq 25 \mathrm{~mm}$ long) galls; short galls were calculated as the percentage of total galls. Each datum point is the average of four 20-tree observations; $+=$ mean of multivariate cluster. There is one hidden observation in both R1 and S1.

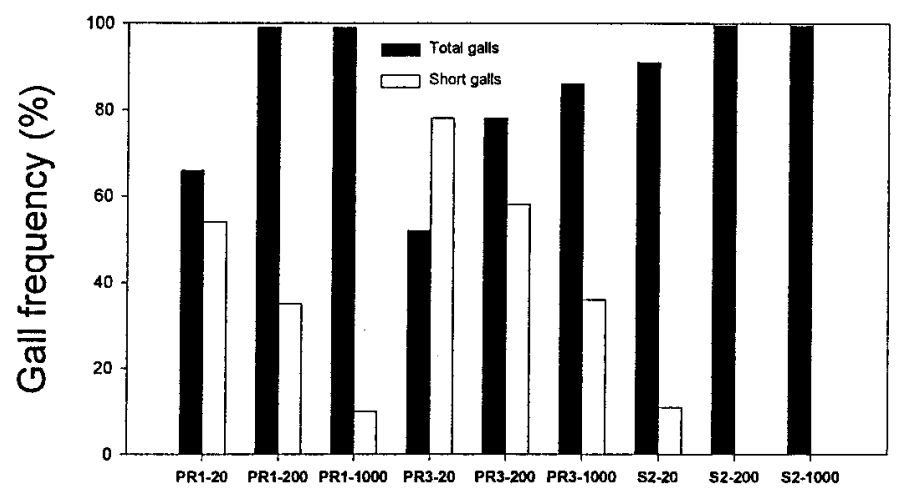

Inoculum concentration (1000 basidiospores $/ \mathrm{ml}$ )

Fig. 4. Response of seedling progeny of resistant (PR1, PR3) and susceptible (S2) open-pollinated slash pine families inoculated in the greenhouse at three spore concentrations $\left(2 \times 10^{4}, 2 \times 10^{5}\right.$, and $\left.1 \times 10^{6}\right)$. Total galls are the percentage of seedlings with a gall including large (> $25 \mathrm{~mm} \mathrm{long}$ ) and short ( $\leq 25 \mathrm{~mm}$ long) galls; short galls were calculated as the percentage of total galls. Each datum point is the average of four 20-tree observations. 
discontinuous pathosystem and pines are allo-infected by haploid basidiospores following genetic recombination and segregation. Qualitative major gene resistance is associated with discontinuous, allo-infectious pathosystems (31); a major gene is identified in the white pine blister rust pathosystem $(13,14)$. Host and pathogen specificity characteristic of complimentary genes is reported in the slash pine- and loblolly pine-fusiform rust pathosystems from field and greenhouse studies (16,19,20,28,33,

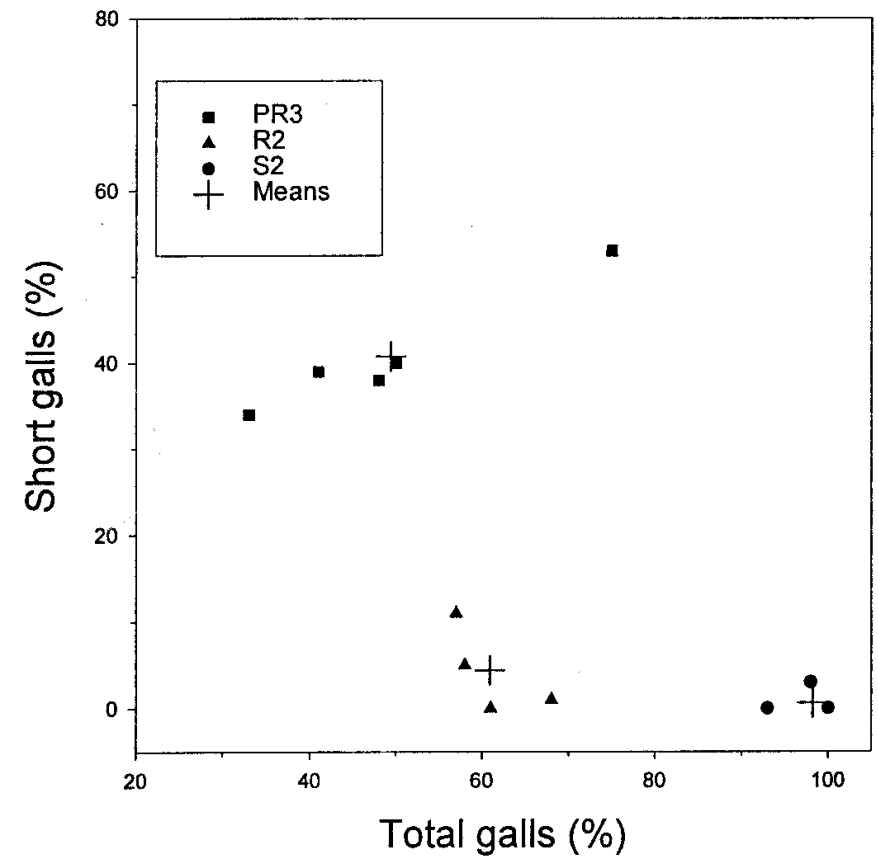

Fig. 5. Response of seedling progeny of resistant (PR3, R2) and susceptible (S2) open-pollinated slash pine families wound-inoculated in the greenhouse with mixed-gall inocula. Total galls are the percentage of seedlings with a gall including large ( $>25 \mathrm{~mm}$ long) and short ( $\leq 25 \mathrm{~mm}$ long) galls; short galls were calculated as the percentage of total galls. Each datum point is the average of four 20-tree observations; + = mean of multivariate cluster. There is one hidden observation in R2 and there are two hidden observations in S2.

TABLE 1. Cumulative fusiform rust incidence and severity at age 5 years on slash pine families ${ }^{\mathrm{w}}$

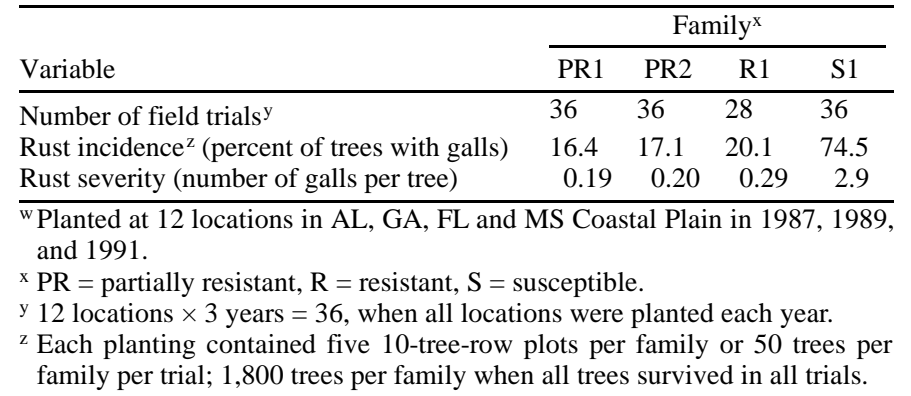

$34,42,44,48,51)$, and major genes for resistance are identified $(1,53)$. The current epidemic is the result of a lowered natural defense profile associated with intensive plantation management (32). Specifically, climatic, edaphic, and biotic environmental factors were altered in favor of infection and sporulation by the pathogen, resulting in the high disease incidence and infection rates typical of the current epidemics.

Slash pine, loblolly pine, rust-susceptible oak species, and the fusiform rust pathogen are indigenous to the southeastern United States. These species have coevolved in a wildtype population with great host and pathogen variability. Squillace (47) found that slash pine exhibited variability in botanical features that were present as a continuous rather than as unique discontinuous subpopulation (provenances). Unlike loblolly pine, provenances of slash pine, which differ significantly for adaptation to unique environments (ecotypes) or for rust resistance, have not been identified. Pathogenic variability in $C$. quercuum f. sp. fusiforme has been described $(28,29,43)$. Many indigenous oak species and natural hybrids abound in this center of origin and their relative susceptibility to $C$. quercuum f. sp. fusiforme has been characterized (5). This indigenous pathosystem appears similar to the wild progenitor's populations of cereal grains which display great diversity of host and pathogen and of resistant mechanisms, suggesting both qualitative and quantitative inheritance (37).

Initial selection of slash pine (selected primarily for improved volume growth and form) occurred in natural stands where fusiform rust was absent or of low frequency (10). These early selections were subject to low selection pressure from the pathogen and likely represent a random selection for conserved rust resistance genes (qualitative and quantitative). Kinloch and Stonecypher (15) found significant additive genetic variation for rust resistance in a randomly selected loblolly pine population. Others have reported significant additive genetic variation for rust resistance in selected populations of slash and loblolly pines $(3,40,45)$. These and other studies $(7,9,35,46)$ which identified resistant slash pine did so in field progeny tests exposed to wildtype inoculum or in greenhouse tests using mixed-gall inoculum.

TABLE 3. Sporulation on large and short fusiform rust galls on slash pine seedlings in the greenhouse

\begin{tabular}{lccccc}
\hline & \multicolumn{2}{c}{ First year } & & \multicolumn{2}{c}{ Second year } \\
\cline { 2 - 3 } \cline { 5 - 6 } $\begin{array}{l}\text { Reaction type } \\
\text { (gall size })^{\mathrm{x}}\end{array}$ & $\begin{array}{c}\text { Number } \\
\text { of galls }\end{array}$ & $\begin{array}{c}\text { Percent with pycnial } \\
\text { or aecial sori }\end{array}$ & & $\begin{array}{c}\text { Number } \\
\text { of galls }\end{array}$ & $\begin{array}{c}\text { Percent with } \\
\text { aecial sori }\end{array}$ \\
\hline Large & 312 & $92.3 \mathrm{a}$ & & 181 & $49.2 \mathrm{a}$ \\
Short & 153 & $40.5 \mathrm{~b}$ & & 136 & $2.9 \mathrm{~b}$ \\
Total & 465 & & & $317^{\mathrm{z}}$ & \\
\hline
\end{tabular}

${ }^{\mathrm{x}}$ Large galls $>25 \mathrm{~mm}$ long; short galls $\leq 25 \mathrm{~mm}$ long at 9 months of age.

y Unlike small letters in columns indicate that sporulation on large and short galls differed significantly $(P=0.0001)$.

$\mathrm{z} 148$ seedlings died between the first and the second year.

TABLE 2. Frequency of sporulation of fusiform rust galls on greenhouse-grown seedlings of slash pine families inoculated at 6 weeks of age with 20,000 basidiospores per $\mathrm{ml}$ of $\mathrm{H}_{2} \mathrm{O}$

\begin{tabular}{lccccc}
\hline & & & & Sporulation (\% of galls) \\
\cline { 4 - 6 } Family $^{\mathrm{w}}$ & Number of galls & Pycnial sori only & Aecial sori only & Pycnial and aecial sori & Pycnial and/or aecial sori \\
\hline Large galls $^{\mathrm{x}}$ & & & & & 3.1 \\
$\quad$ PR3 & 32 & 6.3 & 15.6 & 55.0 & $25.0 \mathrm{a}^{\mathrm{y}}$ \\
R2 & 40 & 22.5 & 20.0 & $97.5 \mathrm{~b}$ \\
S2 & 39 & 30.8 & 38.5 & 28.2 & $97.5 \mathrm{~b}$ \\
Predominately short galls $^{\mathrm{z}}$ & 133 & 5.3 & 2.3 & 0 & 7.5 \\
$\quad$ PR3 & & & & \\
\hline
\end{tabular}

${ }^{\mathrm{w}} \mathrm{PR}=$ partially resistant; $\mathrm{R}=$ resistant; $\mathrm{S}=$ susceptible

x Large galls $>25 \mathrm{~mm}$ long.

y Unlike small letters in columns indicate that families differed significantly $(P=0.0001)$.

${ }^{z}$ Short galls $\leq 25 \mathrm{~mm}$ long at 9 months of age. 
Notwithstanding the genetic heterogeneity of the host and the diverse inocula in our test, some resistant slash pine families consistently exhibited components of partial resistance in greenhouse tests. These families often performed best in diverse field trials, exhibiting the lowest disease incidence and severity and the greatest stability.

\section{ACKNOWLEDGMENTS}

Thanks to the Forest Biology Research Cooperative at the School of Forest Resources and Conservation and R. C. Littell, Professor of Statistics, Institute of Food and Agricultural Sciences, University of Florida.

\section{LITERATURE CITED}

1. Amerson, H. V., Jordan, A. P., Kuhlman, E. G., O’Malley, D. M., and Sederoff, R. R. 1997. Genetic basis of fusiform rust resistance in loblolly pine. (Abstr.) Page 403 in: Proc. 24th South. For. Tree Improv. Conf. Orlando FL. The Southern Forest Tree Improvement Committee.

2. Barber, J. C., Dorman, K. W., and Bauer, E. 1957. Slash pine progeny tests indicate genetic variation in resistance to rust. U. S. Dept. Agric. For. Serv., Southeast. For. Exp. Stn. Res. Note 104.

3. Blair, R. L. and Zobel, B. J. 1971. Predictions of expected gains in resistance to fusiform rust in loblolly pine. Pages 52-57 in: Proc. 11th South. For. Tree Improv. Conf. Atlanta, GA. The Southern Forest Tree Improvement Committee.

4. Chappelka, A. H., III, Schmidt, R. A., and Patterson, H. D. 1984. Dynamics of aeciospore inoculum production by Cronartium quercuum f. sp. fusiforme on slash pine. For. Sci. 30:787-792.

5. Dwinell, L. D. 1974. Susceptibility of southern oaks to Cronartium fusiforme and Cronartium quercuum. Phytopathology 64:400-403.

6. Eskes, A. B. 1983. Incomplete resistance to coffee leaf rust. Pages 291315 in: Durable Resistance in Crops. Plenum Press, New York.

7. Goddard, R. E., and Schmidt, R. A. 1971. Early identification of fusiform rust resistant slash pine families through controlled inoculation. Pages 31-36 in: Proc. 11th South. For. Tree Improv. Conf. Atlanta, GA. The Southern Forest Tree Improvement Committee.

8. Goddard R. E., and Schmidt, R. A. 1979. Relative geographic stability of resistance to fusiform rust of selected slash pine families. Pages 99-107 in: Proc. 15th South. For. Tree Improv. Conf. MS State Univ. The Southern Forest Tree Improvement Committee.

9. Goddard, R. E., Schmidt, R. A., and Vande Linde, F. 1975. Effect of differential selection pressure on fusiform rust resistance in phenotypic selection of slash pine. Phytopathology 65:336-338.

10. Griggs, M. M., and Schmidt, R. A. 1977. Increase and spread of fusiform rust. Pages 32-38 in: Management of Fusiform Rust in Southern Pines. Symp. Proc. Univ. Fla., Gainesville.

11. Hoff, R. J., and McDonald, G. I. 1980. Improving rust-resistant strains of western white pine. U. S. Dept. Agric. For. Serv. Res. Pap. 245

12. Jewell, F. F. 1960. Inoculation of slash pine seedlings with Cronartium fusiforme. Phytopathology 50:48-51.

13. Kinloch, B. B., Jr., and Byler, J. W. 1980. Relative effectiveness and stability of different resistance mechanisms to white pine blister rust in sugar pine. Phytopathology 71:386-391.

14. Kinloch, B. B., Jr., Park, G. K., and Fowler, C. W. 1970. White pine blister rust: simple inherited resistance in sugar pine. Science 167:193-195.

15. Kinloch, B. B., Jr., and Stonecypher, R. W. 1969. Genetic variation in susceptibility to fusiform rust in seedlings from a wild population of loblolly pine. Phytopathology 59:1246-1255.

16. Kinloch, B. B., Jr., and Walkinshaw, C. H. 1991. Resistance to fusiform rust in southern pines: How is it inherited? Pages 219-228 in: Proc. Int. Union For. Res. Org. Work. Party Conf. Rusts of pine. Banff Can. [Can. Northwest Region Info. Rept. NOR-X-317]

17. Knighten, J. L., Young, C. H., McCartney, T. C., and Anderson, R. L. 1988. Resistance Screening Center procedures manual: A step-by-step guide used in the operational screening of southern pines for resistance to fusiform rust. U.S. Dept. Agric. For. Serv., For. Pest Manage. Asheville, NC.

18. Kuhlman, E. G. 1981. Sporulation by Cronartium quercuum f. sp. fusiforme on loblolly and slash pine. Phytopathology 71:345-347.

19. Kuhlman, E. G. 1990. Frequency of single-gall isolates of Cronartium quercuum $\mathrm{f}$. sp. fusiforme with virulence toward three resistant loblolly pine families. Phytopathology 80:614-617.

20. Kuhlman, E. G., Amerson, H. V., Jordan, A. P., and Pepper, J. O. 1997. Inoculum density and expression of major gene resistance to fusiform rust disease in loblolly pine. Plant Dis. 71:597-600

21. Kuhlman, E. G., and Matthews, F. R. 1985. Pine host and rust source affect sporulation of Cronartium quercuum f. sp. fusiforme. Pages 259270 in: Proc. Int. Union For. Res. Org. Work. Group. Rust of hard pines. Athens, GA.

22. McDonald, G. I., and Dekker-Robertson, D. L. 1998. Long-term differential expressions of blister rust resistance in western white pine. Pages 285-295 in: Proc. Int. Union For. Res. Org. Work. Party Conf. Rusts of forest trees. Saariselka Fin. [Fin. For. Res. Inst. Res. Pap. 712]

23. Miller, T., Cowling, E. B., Powers, H. R., Jr., and Blalock, T. E. 1976. Types of resistance and compatibility in slash pine seedlings infected by Cronartium fusiforme. Phytopathology 66:1229-1235.

24. Miller, T., and Schmidt, R. A. 1994. Infection of slash and loblolly pine seedlings by basidiospores of Cronartium quercuum f. sp. fusiforme through stem wounds. (Abstr.) Phytopathology 84:1096.

25. Miller, T., and Schmidt, R. A. 1997. Influence of season on the host responses of slash and loblolly pine seedlings wound-inoculated with basidiospores of Cronartium quercuum f. sp. fusiforme. (Abstr.) Phytopath. Suppl. 86:40.

26. Parlevliet, J. E. 1979. Components of resistance that reduce the rate of epidemic development. Annu. Rev. Phytopathol. 17:203-222.

27. Parlevliet, J. E., and Kuiper, H. J. 1977. Partial resistance of barley to leaf rust; Puccinia hordei, IV. Effect of cultivar and development stage on infection frequency. Euphytica 26:249-255.

28. Powers, H. R., Jr. 1980. Pathogenic variation among single-aeciospore isolates of Cronartium quercuum f. sp. fusiforme. For. Sci. 26:280-282.

29. Powers, H. R., Jr., Matthews, F. R., and Dwinell, L. D. 1977. Evaluation of pathogenetic variabiity of Cronartium quercuum on loblolly pine in the southern USA. Phytopathology. 67:1403-1407.

30. Prakash, C. S., and Thielges, B. A. 1989. Somaclonal variation in eastern cottonwood to race-specific partial resistance to leaf rust disease. Phytopathology 79:805-808.

31. Robinson, R. A. 1987. Host Management in Crop Pathosystems. MacMillan Publ. Co., New York.

32. Schmidt, R. A. 1978. Diseases in forest ecosystems: The importance of functional diversity. Pages 287-315 in: Plant Disease: An Advanced Treatise. Vol. II. How disease develops in populations. Academic Press, New York.

33. Schmidt, R. A., and Allen, J. E. 1997. Fusiform rust epidemics in family mixtures of susceptible and resistant slash and loblolly pines. Pages 309319 in: Proc. 24th South. For. Tree Improv. Conf. Orlando, FL. The Southern Forest Tree Improvement Committee.

34. Schmidt, R. A., and Allen, J. E. 1998. Spatial stability of fusiform rust resistance in slash pine in the coastal plain of the southeastern USA. Pages 219-229 in: Proc. Int. Union For. Res. Org. Work. Party Conf. Rusts of forest trees. Saariselka, Fin. [Fin. For. Res. Inst. Res. Pap. 712].

35. Schmidt, R. A., and Goddard, R. E. 1971. Preliminary results of fusiform rust resistance from field progeny tests of selected slash pines. Pages 3744 in: Proc. 11th South. For. Tree Improv. Conf., Atlanta, GA. The Southern Forest Tree Improvement Committee.

36. Schmidt, R. A., and Miller, T. 1999. Influence of inoculum concentration on production of spermogonia and aecia on pine seedlings infected by basidiospores of Cronartium quercuum f. sp. fusiforme. Plant Dis. 83:367-370.

37. Segal, A., Manisterski, J., Fischbeck, G., and Wahl, I. 1980. How plant populations defend themselves in natural ecosystems. Pages 75-102 in: Plant Disease: An Advanced Treatise. Vol. V. How plants defend themselves. Academic Press, New York.

38. Sharp, E. L. 1983. Experience using durable resistance in the USA. Pages 385-396 in: Durable Resistance in Crops. Plenum Press, New York.

39. Simmonds, N. W. 1991. Genetics of horizontal resistance to disease of crops. Biol. Rev. 66:189-241.

40. Sluder, E. R. 1993. Results at age 15 years from a half-diallel cross among 10 loblolly pines selected for resistance to fusiform rust (Cronartium quercuum f. sp. fusiforme). Silvae Genet. 42:223-230.

41. Snow, G. A. 1991. Gall shape as an indicator of resistance to fusiform rust in loblolly pine. Pages 265-267 in: Proc. Int. Union For. Res. Org. Work. Party Conf. Rusts of pine. Banff, Alberta. [Can. Northwest Region Info. Rept. NOR-X-317].

42. Snow, G. A., Dinus, R. J., and Kais, A. G. 1975. Variation in pathogenicity of diverse sources of Cronartium fusiforme on selected slash pine families. Phytopathology 65:170-175.

43. Snow, G. A., Dinus, R. J., Powers, H. R., Jr., and Matthews, F. R. 1977. Influence of pathogenic variability and inoculum density on fusiform rust. Pages 71-79 in: Management of Fusiform Rust in Southern Pines. Symp. Proc. Univ. FL, Gainesville.

44. Snow, G. A., and Griggs, M. M. 1980. Relative virulence of Cronartium quercuum f. sp. fusiforme from seven resistant families of slash pine. Phytopathol. Med. 19:13-16.

45. Sohn, S. I., and Goddard, R. E. 1979. Influence of infection percent on improvement of fusiform rust resistance in slash pine. Silvae Genet. 
28:173-180.

46. Sohn, S. I., Goddard, R. E., and Schmidt, R. A. 1975. Comparative performances of slash pine for fusiform rust resistance in high rust hazard locations. Pages 204-211 in: Proc. 13th South. For. Tree Improv. Conf., Raleigh, NC. The Southern Forest Tree Improvement Committee.

47. Squillace, A. E. 1966. Geographic variation in slash pine. For. Sci. Mono. 10.

48. Stelzer, H. E., Doudrick, R. L., Kubisiak, T. L., and Nelson, C. D. 1997. Derivation of host and pathogen genotypes in the fusiform rust pathosystem on slash pine, using a complimentary genetics model and diallel data. Pages 320-330 in: Proc. 24th South. For. Tree Improv. Conf. Orlando, FL. The Southern Forest Tree Improvement Committee.

49. Walkinshaw, C. H. 1999. Promising resistance to fusiform rust from southeastern slash pines. U.S. Dept. Agric. For. Serv. Res. Pap. SRS-16.
50. Walkinshaw, C. H., and Anderson, R. L. 1988. How to classify fusiform rust galls on infected loblolly and slash pines. U.S. Dept. Agric. For. Serv. Protect. Rep. R8-PR14.

51. Walkinshaw, C. H., and Bey, C. F. 1981. Reaction of field-resistant slash pines to selected isolates of Cronartium quercuum f. sp. fusiforme. Phytopathology 71:1090-1092.

52. Walkinshaw, C. H., Dell, T. R., and Hubbard, S. D. 1980. Predicting field performance of slash pine families from inoculated greenhouse seedlings. U.S. Dept. Agric. For. Serv., South. For. Exp. Stn. Res. Pap. SO-160.

53. Wilcox, P. L., Amerson, H. V., Kuhlman, E. G., Liu, B. H., O’Malley, D. M., and Sederoff, R. R. 1996. Detection of a major gene for resistance to fusiform rust disease in loblolly pine by genomic mapping. Pages 38593864 in: Proc. Natl. Acad. Sci., USA Vol. 93. Applied Biol. Sci. 